Tarbawi : Jurnal Ilmu Pendidikan p-ISSN:1858-1080 | e-ISSN: 2615-6547

Vol. 16, No. 1, Juli 2020, 1 - 10

\title{
Kemampuan Kimia dan Matematika Siswa MAN 2 Kota Jambi: Relasi dalam Fakta
}

\author{
Desy Rosmalinda \\ Universitas Islam Negeri Sulthan Thaha Saifuddin Jambi \\ E-mail: desyrosmalinda@uinjambi.ac.id
}

\begin{abstract}
Abstrak. Kimia merupakan cabang ilmu alam yang harus siswa kuasai, sama halnya dengan Biologi dan Fisika. Banyak hal yang menjadi kendala siswa selama mempelajari kimia, termasuk saat mengerjakan soal-soal kimia yang mengandung perhitungan matematis. Penelitian ini bertujuan untuk mengetahui kemampuan kimia dan matematika siswa Madrasah Aliyah Negeri 2 Kota Jambi dalam konteks relasi sesuai fakta di lapangan. Jenis penelitian ini yaitu deskriptif kualitatif. Pengumpulan data dilakukan dengan menggunakan tes tertulis dan juga wawancara. Hasil penelitian menunjukkan bahwa siswa yang tidak bisa menjawab soal kimia dengan benar, ternyata bisa menjawab soal matematika yang memiliki operasi matematis yang sama dengan soal kimia tersebut. Berdasarkan hasil wawancara diperoleh informasi bahwa sebanyak $66,7 \%$ siswa mengalami kendala memahami konsep. Dari penelitian ini didapat beberapa fakta menarik. Fakta pertama, siswa yang memiliki kemampuan kimia rendah ternyata tidak selalu memiliki kemampuan matematika yang lemah. Fakta kedua, kendala yang dihadapi banyak siswa dalam mempelajari kimia yaitu sulitnya memahami konsep. Fakta ketiga, metode mengajar guru juga menentukan tingkat ketertarikan siswa untuk mempelajari kimia yang pada akhirnya juga berpengaruh terhadap kemampuan kimia siswa. Fakta keempat, minat siswa untuk mempelajari kimia menjadi faktor internal siswa untuk dapat meningkatkan kemampuan kimianya. Fakta kelima, rajin berlatih mengerjakan soal kimia merupakan salah satu cara mengasah kemampuan kimia. Berdasarkan fakta-fakta tersebut dapat ditarik kesimpulan bahwa kemampuan matematika siswa tidak menjadi faktor utama dari tinggi dan rendahnya kemampuan kimia siswa.
\end{abstract}

Kata kunci: Kemampuan Kimia, Kemampuan Matematika, Relasi Kimia dan Matematika

\begin{abstract}
Chemistry is a part of natural science that students have to master like as Biology and Physics. Many Problem that students have in chemistry studies, including how to solve calculation problems. This study aims to determine the chemical and mathematical abilities of Madrasah Aliyah students in the context of relationships according to facts. The type of research is descriptive qualitative. Data collection was carried out using written tests and interviews. The results showed that students who could not answer chemistry questions correctly could answer mathematical problems that had the same mathematical operations as those chemistry questions. Based on the result of the interview obtained information as much as $66,7 \%$ of students have problems understanding the concept. Several interesting facts were obtained from research. The first fact, students who have weak chemical abilities do not always have weak mathematical abilities. The second fact, the student's problem of studying chemistry is the difficulty of understanding concepts. The third fact, the teacher's teaching method also determines the level of student interest in learning chemistry and also influences students' chemical abilities. The fourth fact, student's interest in studying chemistry is an internal factor to be able to improve their chemical abilities. The fifth fact, always practicing solve chemistry question is one way to boost the ability of chemistry. Based on these facts, it can be concluded that the student's mathematical ability is not a major factor of student's high and low chemistry ability.
\end{abstract}

Keywords: Chemical Ability, Mathematical Ability, Chemical and Mathematical Relation 


\section{PENDAHULUAN}

Kimia merupakan salah satu rumpun sains yang yang harus dikuasai oleh siswa jurusan matematika dan ilmu pengetahuan alam. Namun bukan hal baru bahwa kimia juga menjadi salah satu pelajaran yang dianggap sulit bagi siswa (Guci, Zainul, \& Azhar, 2017). Perhitungan matematis serta konsep yang banyak dan abstrak menjadi beberapa alasan siswa enggan menyukai kimia. Konsep kimia yang bersifat abstrak membuat siswa perlu beimajinasi untuk menggambarkan hal yang tidak dapat dilihat (Eskandar, Bayrami, Vahedi, \& Ansar, 2013). Banyak perhitungan pada ilmu kimia sehingga diperlukan kemampuan matematika yang berhubungan dengan studi tentang struktur, kuantitas, perubahan dan ruang (Israni, 2016). Spencer (Xu, Lewis, \& E., 2013) mengatakan bahwa kemampuan matematika telah lama dianggap penting untuk pencapaian kimia. Rendahnya hasil belajar kimia siswa seringkali dikaitkan dengan lemahnya kemampuan matematika siswa (Merdekawati, 2013).

Hasil penelitian Bangash dan Mustafa mengklaim bahwa siswa banyak yang mengalami kegagalan dalam pembelajaran kimia karena tidak adanya atau rendahnya persiapan matematika siswa tersebut (Potgieter, Harding, \& Engelbrech, 2008). Selain digunakan dalam penyelesaian soal kimia, matematika juga digunakan dalam kegiatan eksperimen. Kimia membutuhkan matematika untuk merasionalisasi observasi dan eksperimen-eksperimen (Trinajstic \& Gutman, 2002). Hubungan kimia dan matematika juga tergambar secara jelas pada konsep kimia kuantum maupun kimia fisika. Pada kimia kuantum terdapat penyelesaian persamaan diferensial, sedangkan pada kimia fisika adanya penyelesaian masalah untuk semua jenis listrik, kondisi batasan dan kekuatannya (Israni, 2016). Pernyataan-pernyataan tersebut berhasil menggiring opini awal peneliti bahwa matematika merupakan modal utama siswa untuk berhasil dalam mempelajari kimia.

Namun informasi sebaliknya diperoleh dari Kurniawati, dkk., (2017) yang meneliti tentang deskripsi kemampuan matematika dan korelasinya dengan hasil belajar siswa pada mata pelajaran kimia kelas X MIPA SMA Negeri 4 Pontianak. Korelasi kemampan matematika diteliti terhadap hasil belajar siswa pada beberapa materi kimia kelas X. Hasil penelitian menunjukkan tidak terdapat korelasi yang signifikan antara kemampuan matematika dengan hasil belajar kimia siswa. Berdasarkan temuan tersebut maka peneliti tertarik melakukan riset melihat hubungan antara kemampuan kimia dan matematika siswa untuk siswa Madrasah Aliyah Negeri 2 Kota Jambi. Peneliti menganalisis relasi kedua ilmu tersebut sesuai fakta yang ditemukan di lapangan. Pada penelitian ini peneliti menggunakan jenis penelitian deskriptif kualitatif, karena peneliti ingin menelaah lebih mendalam temuan-temuan pada saat penelitian. 


\section{METODE}

Penelitian ini merupakan penelitian deskriptif kualitatif. Gambaran hubungan yang akurat karakteristik suatu fenomena menjadi fokus utama penelitian deskriptif (Johnson \& Christensen, 2014). Sedangkan penggunaan pendekatan kualitatif bertujuan untuk mengungkap suatu masalah dan menjabarkan secara mendalam untuk memahami pusat peristiwa dari sebuah masalah (Creswell, 2012). Fokus yang dideskripsikan disini yaitu relasi kemampuan kimia dan matematika siswa dalam sudut pandang siswa itu sendiri. Subjek pada penelitian ini yaitu dua belas siswa MAN 2 Kota Jambi yang terdiri dari tiga kategori, yaitu empat siswa dengan kemampuan kimia tinggi, empat siswa dengan kemampuan kimia sedang dan empat siswa dengan kemampuan kimia tinggi. Penentuan siswa yang menjadi subjek penelitian dilakukan oleh guru kimia MAN 2 Kota Jambi, sebagai pihak yang benar-benar memahami kemampuan siswa-siswa tersebut. Nilai akhir mata pelajaran kimia kelas XI serta keaktifan siswa selama belajar kimia menjadi dasar guru dalam mengelompokan kemampuan siswa-siswa tersebut.

Teknik yang digunakan dalam pengumpulan data yaitu tes tertulis kimia, tes tertulis matematika dan wawancara terhadap subjek penelitian. Sesuai dengan teknik pengumpulan data yang digunakan, maka instrumen pada penelitian ini berupa soal kimia, soal matematika serta pedoman wawancara. Soal kimia yang diberikan berupa dua buah soal laju reaksi (soal nomor 1 dan 2) serta dua buah soal tentang larutan asam dan basa (soal 3a dan 3b). Pemilihan dua materi ini dikarenakan pada konsep laju reaksi dan larutan asam basa terdapat berbagai macam konsep perhitungan matematika sederhana yang harus dikuasai siswa. Soal matematika yang diberikan merupakan soal-soal matematika sederhana yang memiliki konsep perhitungan yang sama dengan perhitungan soal kimia. Pemetaan soal kimia dan matematika dapat dilihat pada Tabel 1.

Tabel 1. Pemetaan Soal Kimia dan Matematika

\begin{tabular}{cll}
\hline Nomor & \multicolumn{1}{c}{ Materi Soal Kimia } & \multicolumn{1}{c}{ Materi Soal Matematika Yang Mendukung } \\
\hline \multirow{2}{*}{$\begin{array}{c}\text { Laju Reaksi } \\
2\end{array}$} & Laju reaksi & $\begin{array}{l}\text { Penyederhanaan pada operasi bilangan eksponen (nomor 1b, } \\
\text { 1c) } \\
\text { Menentukan nilai } n \text { (nomor 2a, 2b) }\end{array}$ \\
\hline $3 a$ & $\begin{array}{l}\text { Menentukan pH larutan } \\
\text { asam }\end{array}$ & $\begin{array}{l}\text { Penyederhanaan bilangan (nomor 1a) } \\
\text { Lerkalian bilangan bulat dengan bilangan desimal (nomor 3a) }\end{array}$ \\
\hline $3 b$ & $\begin{array}{l}\text { Menentukan pH larutan } \\
\text { basa }\end{array}$ & $\begin{array}{l}\text { Perkalian bilangan desimal dengan bilangan desimal (nomor 3b) } \\
\text { Logaritma (nomor 4) }\end{array}$ \\
\hline
\end{tabular}

Pada lembaran soal kimia peneliti melampirkan rumus-rumus tentang laju rekasi dan larutan asam basa, yang dapat digunakan siswa untuk mencari jawaban soal kimia. Tujunnya agar peneliti dapat melihat tingkat pemahaman konsep yang dimiliki siswa, melalui kemampuan 
memilih rumus yang tepat serta keterampilan menentukan langkah-langkah penyelesaian soal. Penggunaan soal kimia dan soal matematika bertujuan untuk melihat secara nyata kemampuan siswa dalam menyelesaikan soal perhitungan. Pemberian soal matematika yang memiliki konsep perhitungan matematis yang sama dengan soal kimia bertujuan agar peneliti bisa menilai penyebab kegagalan siswa saat menjawab soal kimia, apakah dikarenakan rendahnya kemampuan matematika siswa atau karena tidak paham konsep kimianya. Prosedur pada penelitian ini mengacu pada tahapan prosedur penelitian menurut Bogdan (J Moleong, 2010). Sedangkan untuk analisis data, peneliti mengadopsi tahapan analisis data menurut Creswell. Tahap triangulasi diperlukan guna melihat kelayakan data yang diperoleh. Triangulasi yang digunakan yaitu triangulasi teknik dan sumber. Triangulasi teknik dengan melakukan pengambilan data melalui dua teknik, yaitu tes dan wawancara. Sedangkan triangulasi sumber dengan menggunakan sumber berbeda, yaitu siswa dan guru kimia. Data yang diperoleh dari guru kimia berupa hasil wawancara mengenai kendala yang biasa dihadapi guru selama mengajar kimia, serta kemampuan apa saja yang diperlukan siswa agar berhasil menguasai ilmu kimia.

\section{HASIL}

Sebelum disebarkan kepada siswa terlebih dahulu soal kimia dan matematika divalidasi oleh ahli kimia dan matematika, untuk melihat tingkat kesetaraan kesulitan perhitungan matematis pada soal kimia dan matematika. Data jawaban siswa yang didapatkan ditampilkan dalam bentuk tabel guna mempermudah pembacaaan saat menganalisis data. Nama siswa diberi kode sesuai dengan tingkat kemampuan kimianya. Lebih jelasnya dapat dilihat pada Tabel 2.

Pada tabel 2 tergambar dengan jelas bahwa tingkat kemampuan kimia subjek penelitian cukup bagus. Urutan soal yang paling banyak dijawab oleh siswa yaitu soal nomor 1, 3b dan $3 \mathrm{a}$, sedangkan soal nomor 2 banyak siswa yang tidak dapat menjawabnya. Jika dilihat pada bagian hasil jawaban soal kimia di tabel 2, jumlah siswa yang hanya benar pada konsepnya saja lebih banyak daripada jumlah siswa yang hanya benar perhitungan matematisnya. Pada hasil jawaban soal kemampuan matematika, tergambar bahwa kemampuan matematika siswa sangat bagus karena hanya lima siswa yang memiliki jawaban yang salah sedangkan tujuh siswa lainnya mampu menjawab semua soal dengan benar. 
Tabel 2. Hasil Tes Kemampuan Kimia dan Matematika Siswa MAN 2 Kota Jambi

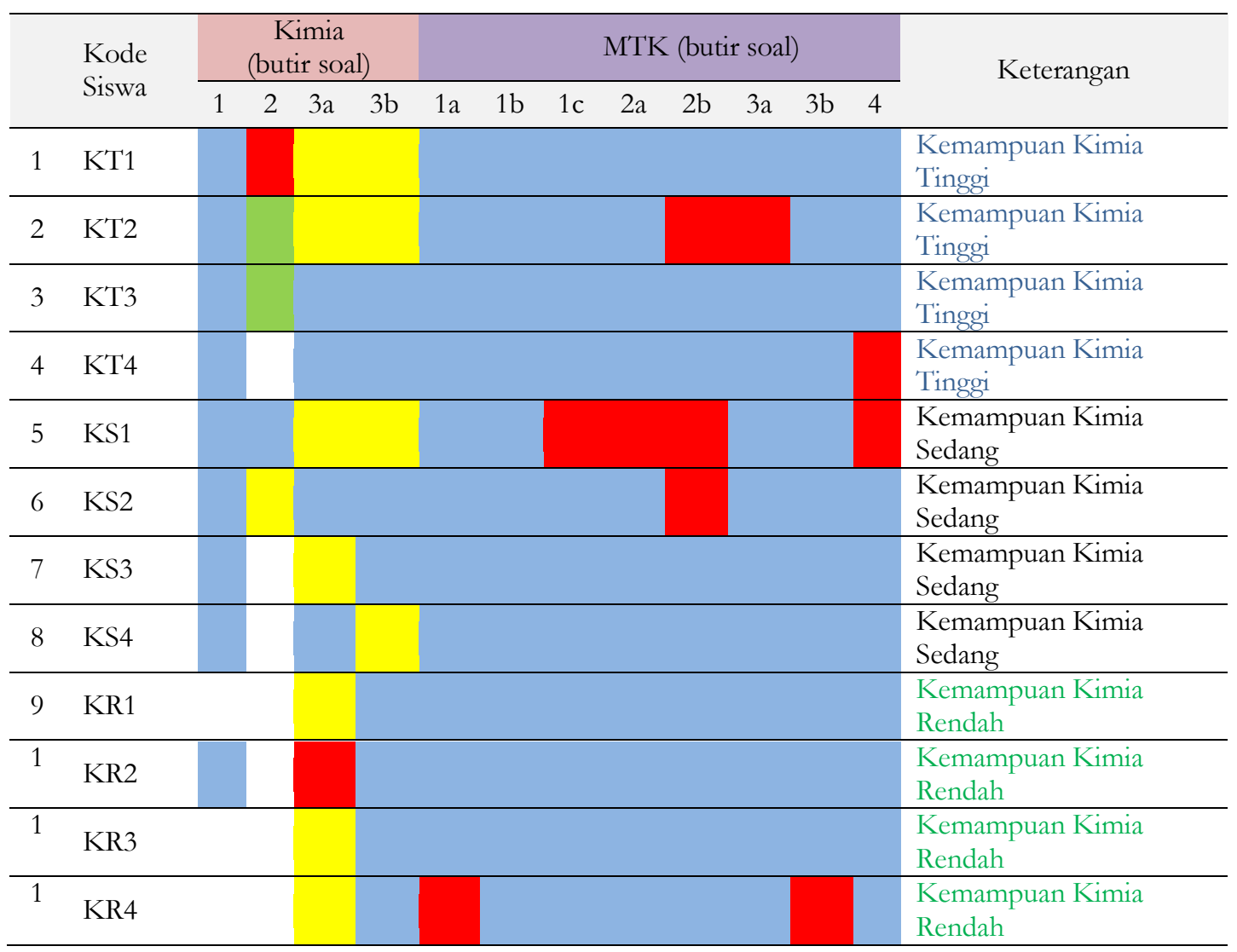

Keterangan warna

\begin{tabular}{|l|l}
\hline & Jawaban benar \\
\cline { 1 - 2 } Jawaban salah total \\
\cline { 1 - 2 } Hanya konsep kimia yang benar (pada soal kimia) \\
Hanya perhitungan matematis yang benar (pada soal kimia) \\
Tidak Jawab
\end{tabular}

\section{DISKUSI}

Kemampuan kimia dan matematika sama-sama sangat dibutuhkan siswa yang mengambil jurusan IPA di SMA maupun Madrash Aliyah. Bahkan matematika sendiri sering dikaitkan memiliki pengaruh yang besar terhadap kesuksesan seseorang mempelajari kimia. Seperti yang dikemukakan Bangash dan Mustafa dalam Potgieter, Harding, \& Engelbrech (2008) mengklaim bahwa siswa banyak yang mengalami kegagalan dalam pembelajaran kimia adalah karena tidak adanya atau rendahnya persiapan matematika siswa. Karena itu peneliti ingin melihat fakta di lapangan bagaimana relasi kedua kemampuan tersebut.

Jika kita menelaah lagi hasil penelitian yang telah didapatkan, rata-rata subjek penelitian memiliki kemampuan menjawab soal matematika yang sangat bagus. Sebanyak 58,3\% siswa yang mampu menjawab semua soal matematika dengan benar. Pada kelompok siswa dengan tingkat 
kemampuan kimia tinggi, sebanyak dua siswa mengalami kesalahan menjawab soal matematika. Siswa pertama menjawab salah pada soal tentang penentuan nilai $n$ dan perkalian bilangan desimal. Sedangkan satu siswa lagi menjawab salah pada soal logaritma. Pada kelompok siswa dengan kemampuan sedang, juga hanya dua orang yang memiliki jawaban matematika yang salah. Bahkan satu diantaranya menjawab salah pada empat soal, yaitu tentang penyederhanaan bilangan eksponen (soal nomor 1c), menentukan nilai $n$ (soal nomor 2a dan 2b) dan juga menentukan nilai logaritma suatu bilangan (soal nomor 4). Sehingga dapat dikatakan siswa tersebut tidak menguasai perhitungan matematis pada konsep-konsep tersebut. Sementara pada kelompok siswa dengan tingkat kemampuan kimia yang rendah, hanya satu siswa yang memiliki jawaban matematika yang salah. Artinya untuk siswa dengan kemampuan kimia rendah, ternyata menguasai perhitungan matematika dengan sangat baik.

Namun untuk soal kimia sendiri masih banyak kesulitan dan kekeliruan yang dihadapi siswa selama menjawab soal. Hal ini terlihat dengan tidak adanya siswa yang berhasil menjawab seluruh soal dengan benar. Berikut gambaran persentase hasil jawaban kimia siswa Madrasah Aliyah Negeri 2 Kota Jambi.

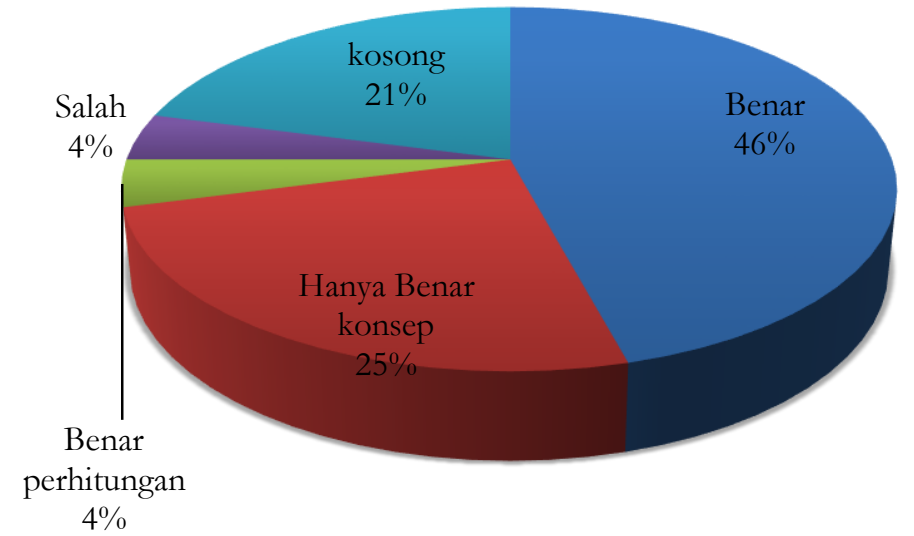

\section{Gambar 1. Diagram Gambaran Persentase Hasil Jawaban Kimia Siswa}

Dari Gambar 1 dapat dilihat bahwa persentase jawaban benar pada keseluruhan soal kimia yang diberikan tidak sampai 50\%, sangat kontras dengan jumlah jawaban benar pada soal matematika. Jika dilihat berdasarkan tingkat kemampuan kimia yang disajikan pada tabel 1, siswa dengan tingkat kemampuan kimia tinggi tampak berusaha menjawab semua soal kimia yang diberikan. Hanya saja masih terdapat kekeliruan baik dari segi konsep maupun perhitungan. Pada siswa dengan tingkat kemampuan kimia sedang terlihat memiliki satu atau dua jawaban yang hanya benar secara konsep kimianya namun salah pada perhitungannya. Bahkan dua siswa tidak menjawab soal nomor 2 dengan alasan tidak bisa menganalisis soal yang diberikan. Sementara itu 
siswa dengan tingkat kemampuan kimia rendah, memiliki jawaban benar yang paling sedikit. Bahkan ada beberapa soal yang memang tidak mereka kerjakan. Dari uraian tersebut, tampak bahwa siswa-siswa tersebut memang sudah bekerja sesuai dengan kapasitas kemampuan masingmasing.

Jika melihat relasi dari hasil tes kemampuan kimia dan matematika siswa-siswa tersebut, siswa yang berhasil menjawab semua soal matematika ternyata masih memiliki kesalahan saat menjawab soal kimia. Misalkan saja siswa dengan kode KT1 yang jawabannya salah pada soal kimia nomor 2, ternyata mampu menjawab soal matematika nomor 1a yang memiliki konsep perhitungan yang sama dengan soal kimia tersebut. Contoh lain pada siswa dengan kode KT2 yang pada soal kimia nomor 3b masih belum tepat. Jawaban siswa tersebut hanya benar secara konsep kimianya, namun untuk operasi perhitungannya salah. Namun ia mampu menjawab soal matematika nomor $3 \mathrm{~b}$ dan nomor 4 yang memiliki konsep perhitungan yang sama dengan soal kimia nomor 3b. Kondisi berbeda terjadi pada siswa dengan kode KS1 dimana siswa tersebut menjawab benar pada soal kimia nomor 2, namun memiliki jawaban yang salah pada soal matematika yang memiliki konsep perhitungan yang sama dengan soal kimia tersebut. Jika mengacu pada pernyataan Bangash dan Mustafa (Potgieter, Harding, \& Engelbrech, 2008) seharunya jika siswa menguasai matematika maka siswa dapat mengerjakan soal kimia yang memiliki konsep perhitungan yang sama dengan soal matematika tersebut. Namun hal ini terpatahkan dengan adanya bukti di lapangan. Bahkan pada tabel 1 terlihat bahwa siswa dengan tingkat kemampuan kimia rendah memiliki kemampuan matematika yang bagus. Seperti yang telah dijelaskan sebelumnya bahwa pada soal kimia dilampirkan rumus-rumus yang dapat digunakan untuk menyelesaikan soal kimia. Seharusnya dengan adanya bantuan rumus yang diberikan dan baiknya kemampuan matematika yang dimiliki siswa, maka siswa dapat menyelesaikan soal kimia dengan benar. Namun pada kenyataannya siswa masih merasa kesulitan dalam menyelesaikan soal. Artinya kemampuan matematika bukan hal utama yang menentukan kesuksesan siswa dalam menyelesaikan soal kimia.

Dari wawancara siswa diperoleh informasi bahwa kendala yang mereka alami selama mengerjakan soal kimia yaitu susah menganalisa soal, bingung mengoperasikan rumus dan urutan langkah penyelesaian soal. Walaupun kimia mengandung banyak perhitungan matematis, namun hanya memiliki kemampuan matematika yang baik saja tidak cukup untuk menyelesaikan soal kimia. Tingkat pemahaman konsep kimia juga menentukan kemampuan siswa dalam menyelesaikan soal-soal perhitungan kimia. Artinya paham operasi perhitungan matematika memang diperlukan dalam menyelesaikan soal kimia, namun pemahaman konsep kimia juga dibutuhkan saat penyelesaian soal. Siswa yang memiliki kemampuan matematika yang bagus 
namun tidak memahami konsep kimia dengan baik, tidak akan mampu menganalisa soal kimia serta menentukan langkah-langkah yang harus digunakan dalam menyelesaikan soal kimia.

Sebanyak 66,7\% siswa menjawab kendala yang mereka hadapi selama belajar kimia yaitu kesulitan saat memahami konsep. Karena hal itulah kimia masuk dalam kategori pelajaran yang tidak disukai siswa. Kesulitan memahami konsep itu sendiri disebabkan ketidaksesuaian metode mengajar yang digunakan guru sehingga tidak bisa membuat siswa tertarik terhadap kimia. Semua unsur lingkungan belajar seperti bahan pelajaran, alat, siswa dan guru saling berkaitan dan mempengaruhi serta berfungsi sesuai dengan tujuan (Selvia Erita, 2016). Guru harus mempunyai persedian startegi dan metode pembelajaran yang bermanfaat dalam proses pembelajaran (Meditamar dkk., 2017). Pembelajaran kimia membutuhkan variasi model pembelajaran karena materinya bervariasi, penggunaan model pembelajaran yang monoton menyebabkan siswa kurang termotivasi (Supardi \& Putri, 2010).

Hal menarik lainnya yang peneliti dapatkan dari wawancara ialah adanya siswa yang tidak menyukai matematika namun pernah menjadi peserta olimpiade kimia. Siswa tersebut menuturkan bahwa matematika memang dibutuhkan untuk menyelesaikan perhitungan kimia namun tidak begitu besar. Karena jika paham matematika namun tidak paham konsepnya, maka tetap tidak akan bisa menentukan langkah dalam menyelesaikan soal yang diberikan. Operasi perhitungan pada soal kimia selalu sama, jika rajin mengerjakan soal maka dengan sendirinya akan terbiasa sehingga bisa mengerjakan soal tersebut. Hal ini sejalan dengan yang diutarakan Ahmad dkk.(2017) bahwa kemampuan pada diri seseorang akan terbentuk jika adanya pembiasaan berpikir secara konsisten dan berkelanjutan.

Selain melakukan wawancara dengan siswa, peneliti juga melakukan wawancara dengan guru kimia sebagai bentuk triangulasi sumber. Berdasarkan hasil wawancara bersama Bapak Drs. Herry Santoso selaku guru kimia MAN 2 Kota Jambi, kendala yang sering dihadapi selama mengajar kimia yaitu karena konsep dasar kimia dan juga matematika dasar yang dimiliki siswa kurang kuat. Terkadang perhitungan pada kimia berhubungan dengan konsep teorinya, sehingga jika konsepnya tidak paham maka otomatis perhitungannya juga tidak paham. Umumnya anakanak yang kimianya bagus, kemampuan matematika dasarnya juga bagus sehingga kemampuan matematika sangan mendukung anak untuk memahami kimia. Tapi tidak menutup kemungkinan siswa yang matematikanya bagus tapi kemampuan kimianya tidak bagus. Itu semua berhubungan dengan minat siswa untuk memahami kimia itu sendiri.

Dari penelitian ini didapat beberapa fakta. Fakta pertama, siswa yang memiliki kemampuan kimia rendah ternyata tidak selalu memiliki kemampuan matematika yang lemah. Fakta kedua, kendala yang dihadapi banyak siswa dalam mempelajari kimia yaitu sulitnya 
memahami konsep. Fakta ketiga, metode mengajar guru juga menentukan tingkat ketertarikan siswa untuk mempelajari kimia yang pada akhirnya juga berpengaruh terhadap kemampuan kimia siswa. Fakta keempat, minat siswa untuk mempelajari kimia menjadi faktor internal siswa untuk dapat meningkatkan kemampuan kimianya. Fakta kelima, rajin berlatih mengerjakan soal kimia merupakan salah satu cara mengasah kemampuan kimia.

Fakta-fakta tersebut sejalan dengan temuah penelitian terdahulu bahwa banyak faktor yang mempengaruhi rendahnya hasil belajar kimia siswa. Faktor penyebab nilai kimia siswa rendah bisa saja dari rendahnya minat dan motivasi belajar siswa, pemaknaan konsep kimia yang rendah, kemampuan matematika yang lemah, atau bisa saja pengaruh lingkungan belajar siswa seperti pengaruh teman dan cara mengajar guru yang kurang pas (Sudiana dkk.,2019). Bahkan penelitian yang dilakukan Kurniawati dkk.(2017) menyebutkan faktor lain yang mempengaruhi hasil belajar kimia siswa yaitu kemampuan siswa dalam memahami konsep-konsep serta kemampuan siswa dalam memadupadankan konsep dan perhitungan matematis dalam menyelesaikan soal kimia. Dengan demikian dapat dikatakan bahwa hasil penelitian ini tidak sejalan dengan pernyataan dari Merdekawati (2013) bahwa siswa dengan kemampuan matematika tinggi memiliki prestasi belajar kimia yang lebih baik dibandingkan siswa dengan siswa kemampuan matematika rendah, serta pernyataan Bangash dan Mustafa (Potgieter, Harding, \& Engelbrech, 2008) bahwa siswa banyak mengalami kegagalan dalam pembelajaran kimia karena rendahnya persiapan matematika siswa.

\section{PENUTUP}

Dari penelitian yang telah dilakukan dapat disimpulkan bahwa lemahnya kemampuan matematika bukan faktor utama yang menyebabkan rendahnya kemampuan kimia siswa. Banyak hal yang bisa menyebabkan rendahnya kemampuan kimia siswa. Seperti kurang menariknya metode mengajar guru, konsep kimia yang sulit, dan ketidakpahaman memadukan antara konsep dan perhitungan matematis, yang semuanya menyebabkan minat siswa mempelajari kimia berkurang. Masih banyak faktor lain yang perlu dipelajari lagi relasinya terhadap kemampuan kimia yang dimiliki siswa, misalkan jenis kelamin siswa, usia, dan dukungan keluarga. Besar harapan dengan didalami lagi relasi faktor-faktor lain dengan kemampuan kimia, dapat menghasilkan solusi guna meningkatkan kemampuan kimia siswa.

\section{REFERENSI}

Ahmad, B., Deswita, R., Ningsih, F., \& Syafriadi. (2017). Core dengan Pendekatan Scientific Terhadap Kemampuan Pemecahan Masalah Matematis dan Mathematical Habits of Mind Mahasiswa Matematika. Jurnal Tarbawi, 13(02), 33-42. 
Creswell, J. W. (2012). Educational Research: Planning, Conducting and Evaluating Quantitative and Qualitative Research. In Pearson (4th ed.). Boston.

Eskandar, F.-A., Bayrami, M., Vahedi, S., \& Ansar, V. A. A. (2013). The effect of instructional analogies in interaction with logical thinking ability on achievement and attitude toward chemistry. Chemistry Education Research and Practice, 14(4), 566-575. https://doi.org/10.1039/C3RP00036B

Guci, S. R. F., Zainul, R., \& Azhar, M. (2017). Pengembangan Media Pembelajaran Berbasis Tiga Level Representasi Menggunakan Prezi Pada Materi Kesetimbangan Kimia. Prodi Pendidikan Kimia Universitas Negeri Padang, November(November), 1-8. https://doi.org/https://doi.org/10.31227/osf.io/n7jkf

Israni, P. (2016). The Relationship of Chemistry with Physics and Mathematics. International Journal of Current Research in Science and Technology, 2(1), 33-35.

J Moleong, L. (2010). Metodologi Penelitian Kualitatif. Bandung: Remaja Rosda Karya.

Johnson, R. B., \& Christensen, L. (2014). Educational Research: Quantitative, Qualitative, and Mixed Approaches (5th ed.). United Sta.

Kurniawati, E., Kurniati, T., \& Kurniawan, R. A. (2017). Deskripsi Kemampuan Matematika dan Korelasinya dengan Hasil Belajar Siswa pada Mata Pelajaran Kimia Kelas X MIPA SMA Negeri 4 Pontianak. Ar-Razi Jurnal Ilmiah, 5(2), 169-180. https://doi.org/10.1017/CBO9781107415324.004

Meditamar, M. O., Gunawan, R. G., Oktafia, M., \& Nurmailis. (2017). Pengaruh Strategi Belajar Murder Dengan Setting Belajar Kelompok Terhadap Kemampuan Pemecahan Masalah Matematika Siswa Smp Negeri 1 Kerinci. Jurnal Tarbawi, 13(01), 11-21.

Merdekawati, K. (2013). Pengaruh Kemampuan Matematik Terhadap. 2(1).

Potgieter, M., Harding, A., \& Engelbrech, J. (2008). Transfer of Algebraic and Graphical Thinking between Mathematics and Chemistry. Journal of Research in Science Teaching, 45(2), 197-218. https://doi.org/10.1002/tea

Selvia Erita. (2016). Beberapa Model, Pendekatan, Strategi, dan Metode dalam Pembelajaran Matematika Oleh: Selvia Erita. Jurnal Tarbawi, 1(2).

Sudiana, I. K. S., Suja, I. W., \& Mulyani, I. (2019). Analisis Kesulitan Belajar Kimia Siswa Pada Materi Kelarutan Dan Hasil Kali Kelarutan. Jurnal Pendidikan Kimia Indonesia, 3(1), 7. https://doi.org/10.23887/jpk.v3i1.20943

Sujadi, Eko. (2017). Penerapan Pendidikan Karakter Cerdas Format Kelompok Untuk Meningkatkan Nilai Kejujuran Mahasiswa Bimbingan Konseling Islam (BKI) Institut Agama Islam Negeri (IAIN) Kerinci. Tarbawi: Jurnal Ilmu Pendidikan, 13(1), 97-108.

Supardi, K. I., \& Putri, I. R. (2010). Pengaruh Penggunaan Artikel Kimia Dari Internet Pada Model Pembelajaran Creative Problem Solving Terhadap Hasil Belajar Kimia Siswa Sma. Jurnal Inovasi Pendidikan Kimia, 4(1), 574-581.

Trinajstic, N., \& Gutman, I. (2002). Mathematical Chemistry. Croatica Chemica Acta, 75(2), 329356. https://doi.org/10.1201/b19046-3

Xu, X., Lewis, S. M. V., \& E., J. (2013). College students' attitudes toward chemistry, conceptual knowledge and achievement: structural equation model analysis. Chemistry Education Research and Practice, 14(2), 188-200. https://doi.org/10.1039/C3RP20170H 